\title{
An Empirical Study on the Influence of Atypical Visitors' Interactive Learning on Exhibition Brand Equity
}

\author{
Wanyun Zhang, Xin Mai, Simin Huang, Peng Ju* \\ Shenzhen Tourism College of Jinan University, Shenzhen, China \\ Email: ${ }^{*}$ jjppsszz@163.com
}

How to cite this paper: Zhang, W. Y., Mai, X., Huang, S. M., \& Ju, P. (2020). An Empirical Study on the Influence of Atypical Visitors' Interactive Learning on Exhibition Brand Equity. iBusiness, 12, 33-51. https://doi.org/10.4236/ib.2020.122003

Received: February 28, 2020

Accepted: April 27, 2020

Published: May 6, 2020

Copyright () 2020 by author(s) and Scientific Research Publishing Inc. This work is licensed under the Creative Commons Attribution International License (CC BY 4.0).

http://creativecommons.org/licenses/by/4.0/

\begin{abstract}
The research data show that more than $90 \%$ of the exhibition visitors are atypical visitors who have no obvious purchase intention, and there are few researches on atypical visitors. Data were collected from the atypical visitors of China Hi-Tech Fair 2019 and selected through questionnaire investigation. This study aims to discuss the influence of atypical visitors' interactive learning on the exhibition brand equity with the methods of literature analysis and empirical study. The findings can provide some supplements for theoretical exploration and practical management.
\end{abstract}

\section{Keywords}

Atypical Visitors, Interactive Learning, Brand Equity, Experience Value, Exhibition Brand

\section{Literature Review}

\subsection{Atypical Visitors}

\subsubsection{Definition of Atypical Visitors}

Exhibition visitors can be divided into buyers and non-buyers, and buyers are also called typical visitors (Godar \& O'Connor, 2001). As for the definition of atypical visitors, some scholars defined atypical visitors from the perspective of behavior. For instance, Spiegel \& Messenund (1992) defined atypical audiences as those aimless loafers and pragmatists. Blythe (2010) stated in the research results that atypical visitors, accounting for $90 \%$, include those price comparators, fake buyers with no intention or ability to buy, technical experts who only want to obtain technical information, cunning people with special purposes and one-day exhibition visitors. 
Some scholars defined exhibition visitors from visitors' objectives. Godar \& O'Connor (2001) stated that exhibition visitors include real buyers, potential buyers and non-buyers. Luo and Bao (2007) divided exhibition visitors into the core layer, the secondary layer and the outer layer, in which the core layer visitors make the greatest contribution to the sales performance of the exhibitors, and the secondary and outer layer visitors have no obvious willingness to buy during the exhibition. Borghini et al. (2006) believed that atypical visitors usually refer to the exhibitors' suppliers, peers and other groups, who mainly come to update products and industries information, and part of media workers, designers, teachers and students for work purposes. In this paper, the definition of atypical visitors of the third one is generally used.

\subsubsection{Atypical Visitors' Interactive Learning}

At present, there are many researches on the interactive relationships of groups participating in the exhibition, but few on atypical visitors' interactive learning. The research on the relationship between the exhibition organizers and the visitors mainly focuses on the establishment of relationship (Blythe, 2002), active communication (Hansen, 1996; Zhang \& Xu, 2019), the mode of information transmission and communication (Rosson \& Seringhaus, 1995), and the establishment of theoretical models (Li, 2005; Lee and Kim, 2008) and so on. He, Cui, \& Wang (2014) one of Chinese scholars, systematically discussed the influence of contact before exhibition and interactive learning during exhibition on exhibition performance, and proposed the value and contribution of atypical visitors for the first time, that is, interactive learning between atypical visitors and exhibitors not only has a direct contribution to exhibitors' participation performance, but also has an indirect contribution to sales performance.

\subsection{Experience Value}

The research on experience value includes brand experience value and consumer experience value, in which the dimension of consumer experience value is at the core of the whole research. The representative viewpoints are as follows. By the dimension of happiness, consumer experience value includes knowledge value, emotional value, social value and physical attribute value (Dube \& Jordan, 2003). Consumer experience itself has values, including functional value, situational value, social value, emotional value and cognitive utility (Sheth, Newman, \& Gross, 1991). There are five types of consumer experience: sense, emotion, thinking, behavior and relationship, and these can be subdivided into eight indicators: aesthetic, sensory quality, emotion, feeling, analysis and synthesis, separation and imagination experience, driving behavior and behavior experience, and social experience namely (Schmitt, 1999). The research perspectives of Chinese scholars are basically similar to those of Sheth and Schmitt. Li and Yu (2011) stated that value experience is the sensory, emotional and social experience that consumers get when consuming brand products, which can promote consumer 
behavior and have an impact on brand equity. And this impact will change due to the experience of brand purchase and the level of consumer involvement ( $\mathrm{Li}$ \& Yu, 2011). Zhang, Chen, and Duan (2018) made a detailed analysis of the experience value of $\mathrm{B} 2 \mathrm{~B}$ exhibition based on the hierarchical experience value model, and put forward some suggestions on the visitors' service marketing strategy of $\mathrm{B} 2 \mathrm{~B}$ exhibition from the three dimensions of basic demand, attribution demand and final demand (Gan, 2013).

\subsection{Exhibition Brand}

At present, there are few empirical studies on exhibition brand equity by Chinese scholars, and only one literature on the formation of exhibition brand equity from the perspective of exhibitors (Gan, 2013). Most studies focus on the concept and brand building. The researches on the concept of exhibition brand can be divided into three forms: manifestation (Wang, 2006), sign (Wang, Zhou, \& Tian, 2008; Hua, 2004) and assets (Zhong, 2007; Yu, 2009). On the researches of brand building, scholars studied and put forward suggestions from the perspectives of market, public, brand (Yoo, Arnold, \& Frankwick, 2012), brand building (Su, 2008), the strategy of experience marketing (Tian \& Wang, 2008), and brand exhibition's cultivation (Ren, 2010). The brand exhibition should have a certain scale, which can reflect the development trend of the industry, and have strong guidance and influence on the industry (Li, 2012).

\subsection{Brand Equity}

\subsubsection{Definition of Brand Equity}

After the changes in three research perspectives of finance, market and consumer, scholars gradually focus on the relationship between consumers and brand equity, with the mainstream research perspective of consumers' cognitive and emotional process of the brand. Brand equity is the expression of brand value formed by the fact that product brands can arouse consumers' attention, perception, desire, experience and changes in psychology and behavior of purchase (Kim, 1990). Brand equity includes brand name and brand identity, which affects the value of products or services to enterprises and consumers (Aaker, 1991). From the perspective of consumers, Keller (1993) defined brand equity as consumers' differentiated perception of the brand, but also a different reflection of brand marketing activities. Chinese scholars also carried out relevant research. Fu (1999) believed that brand equity is the stable development and continuous strengthening of future relationship between consumers and enterprises, which can create additional benefits and value for enterprises. Perceived quality is closely related to brand equity, and consumers' expected perceived quality from brands is the source of brand equity (Ning, 2005). Wang and Liao (2010) found the relationship between brand equity and consumers' emotional changes, and proposed that enterprises should establish a long-term brand monitoring system to achieve real-time management of brand 
equity.

\subsubsection{Brand Equity Model}

At present, the research on brand equity measurement is from the perspective of consumers, among which the influential ones are Aaker's five-dimensional model (Aaker, 1991), Keller's (1993) CBBE model and Yoo and Donthu's (2001) multi-dimensional model. The multi-dimensional model of Yoo and Donthu is widely used.

In 2000, Yoo, B. divided brand equity into value to the company and value to consumers, divided marketing elements into five parts: price, store image, distribution density, advertising investment and price promotion, and divided brand equity into three dimensions: brand awareness/brand association, perceived quality, brand loyalty. Yoo empirically analyzed the influence of marketing mix strategy on brand equity and its dimensions by investigating consumers' perception of marketing mix.

In 2001, according to the concept of brand equity proposed by Aaker and Keller, Yoo and Dothu proposed "the model of consumer-based multi-dimensional brand equity", MBE model for short. This study further confirmed the three dimensions of brand equity in the Yoo, B.'s model, namely, brand awareness/ brand association, perceived quality and brand loyalty, and the proposed model enriched the theoretical knowledge of brand equity research.

\section{Research Design}

\subsection{Dimensions and Indicators of Research Variables}

Based on literature review and previous research results, research variables in this paper are determined by three dimensions: atypical visitors, experience value and exhibition brand equity, 7 variables and 22 measurement indicators in total (Table 1).

\subsection{Research Model and Hypotheses}

\subsubsection{Construction of Research Model}

According to research variables of atypical visitors' interactive learning behavior, experience value and exhibition brand equity determined previously, and the logical relationship between the behavior pattern of atypical visitors and the exhibition brand equity, the research model of the influence of atypical visitors' interactive learning on exhibition brand equity is initially constructed (Figure $1)$.

\subsubsection{Proposal of Research Hypotheses}

According to the above research model and the research purpose of this study, the research hypotheses are put forward on the influence of atypical visitors' interactive learning on the exhibition brand equity:

H1: Atypical visitors' interactive learning with exhibition organizers has a 
Table 1. Research scale design.

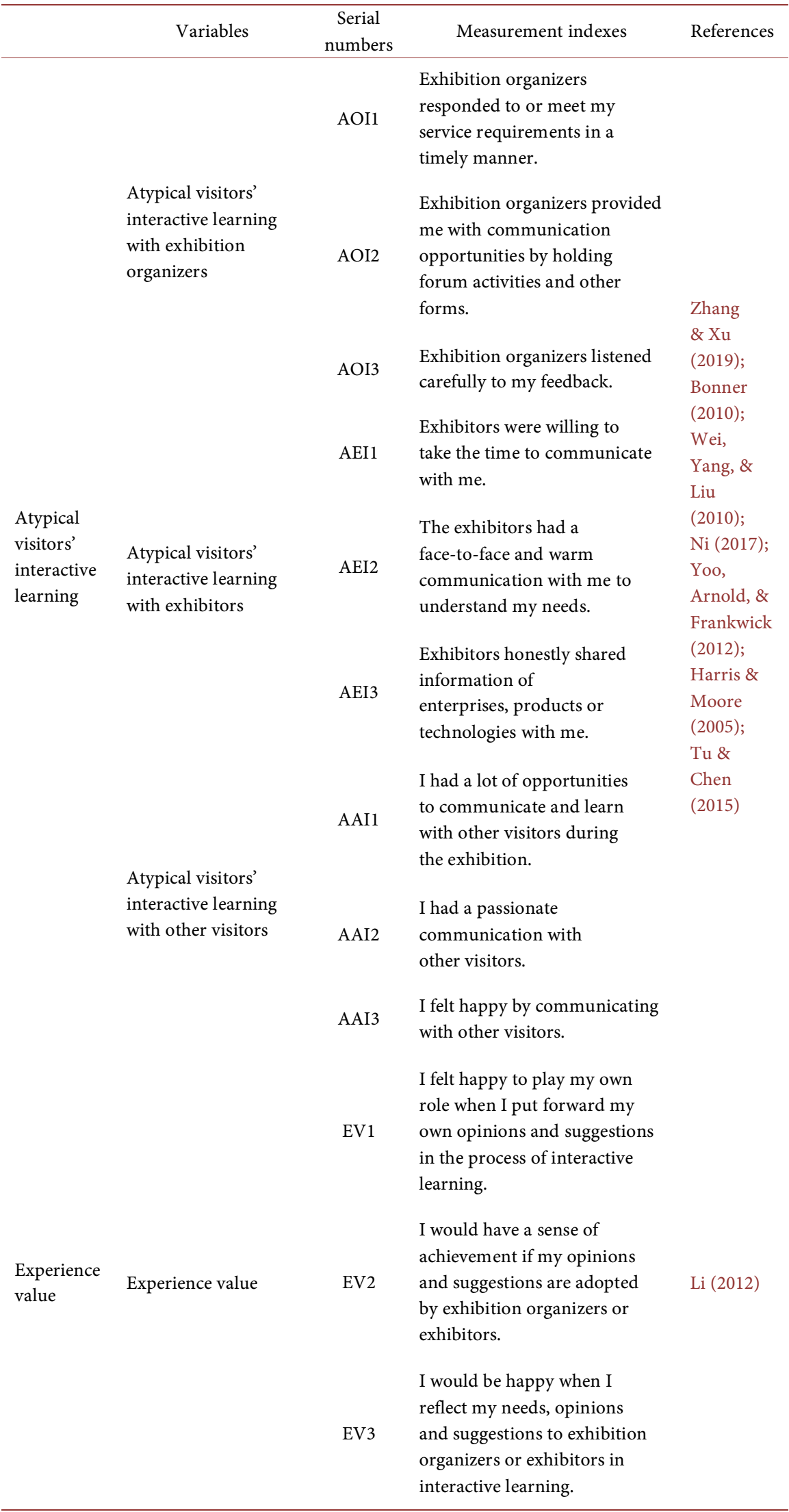




\section{Continued}

\begin{tabular}{|c|c|c|c|c|}
\hline & & EV4 & $\begin{array}{l}\text { Exhibition organizers or } \\
\text { exhibitors would better meet } \\
\text { my needs if I reflect my needs } \\
\text { and put forward opinions and } \\
\text { suggestions to them. }\end{array}$ & \multirow{4}{*}{$\begin{array}{l}\text { Aaker } \\
(1996) ; \\
\text { Keller } \\
\text { (1993); } \\
\text { Kim \& Kim } \\
\text { (2004); }\end{array}$} \\
\hline \multirow{9}{*}{$\begin{array}{l}\text { Exhibition } \\
\text { brand } \\
\text { equity }\end{array}$} & \multirow{3}{*}{$\begin{array}{l}\text { Brand } \\
\text { awareness/association }\end{array}$} & BE1 & $\begin{array}{l}\text { When talking about similar } \\
\text { exhibitions, I often think of } \\
\text { this exhibition. }\end{array}$ & \\
\hline & & BE2 & $\begin{array}{l}\text { I am very familiar with this } \\
\text { exhibition. }\end{array}$ & \\
\hline & & BE3 & $\begin{array}{l}\text { Many people I am familiar } \\
\text { with know about this } \\
\text { exhibition. }\end{array}$ & \\
\hline & \multirow{3}{*}{$\begin{array}{l}\text { Brand's perceived } \\
\text { quality }\end{array}$} & BPQ1 & $\begin{array}{l}\text { I think this is a high-quality } \\
\text { exhibition. }\end{array}$ & $\begin{array}{l}\text { Yoo \& } \\
\text { Donthu } \\
\text { (2001); }\end{array}$ \\
\hline & & BPQ2 & $\begin{array}{l}\text { I think the visitors of this } \\
\text { exhibition are of high quality. }\end{array}$ & $\begin{array}{l}\text { Wang \& He } \\
\text { (2009); } \\
\text { Wang }\end{array}$ \\
\hline & & BPQ3 & $\begin{array}{l}\text { I am satisfied with the service } \\
\text { of the exhibitors in this } \\
\text { exhibition. }\end{array}$ & $\begin{array}{l}(2012) ; \\
\text { Jacoby \& } \\
\text { Robert }\end{array}$ \\
\hline & \multirow{3}{*}{ Brand loyalty } & BL1 & $\begin{array}{l}\text { I will participate in this } \\
\text { exhibition next time. }\end{array}$ & \multirow{3}{*}{$\begin{array}{l}\text { (1978); } \\
\text { Krystallis \& } \\
\text { Chrysochuou } \\
(2014)\end{array}$} \\
\hline & & BL2 & $\begin{array}{l}\text { I will recommend this } \\
\text { exhibition to others. }\end{array}$ & \\
\hline & & BL3 & $\begin{array}{l}\text { I will invite others to visit the } \\
\text { exhibition. }\end{array}$ & \\
\hline
\end{tabular}

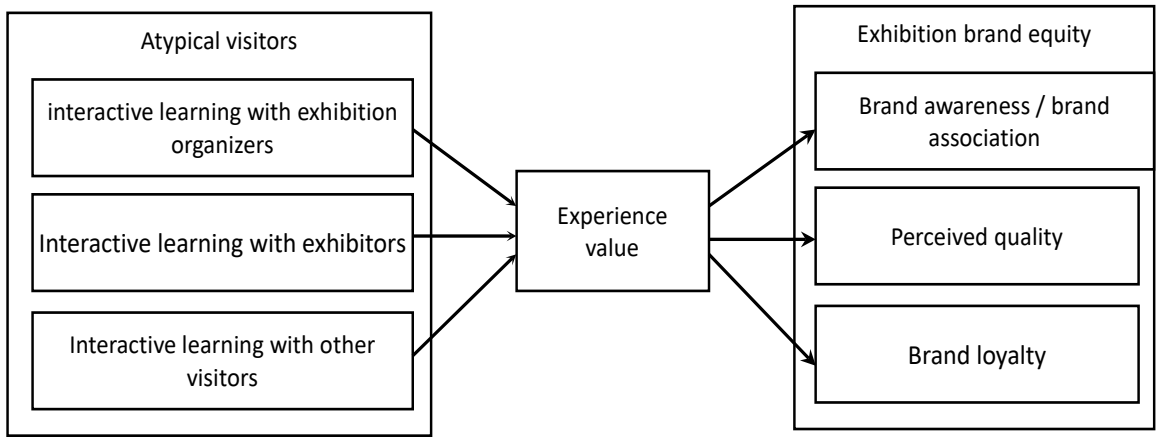

Figure 1. Research model of the influence of atypical visitors' interactive learning on exhibition brand equity.

significantly positive impact on experience value.

H2: Atypical visitors' interactive learning with exhibitors has a significantly positive impact on experience value.

H3: Atypical visitors' interactive learning with other visitors has a significantly positive impact on experience value. 
H4: Experience value has a significantly positive impact on brand awareness.

H5: Experience value has a significantly positive impact on brand's perceived quality.

H6: Experience value has a significantly positive impact on brand loyalty.

All the hypotheses will be tested at part 3 with three methods, they are exploratory factor analysis, correlation analysis and regression analysis.

\subsection{Questionnaire Design and Pre-Survey}

After putting forward the model of the influence of the atypical visitors on the brand equity of the exhibition, the researcher of this paper designs a questionnaire for each variable of the atypical visitors and the brand equity of the exhibition based on the scale proposed by scholars at home and abroad when they study the consumers and brand equity and combined with the characteristics of the exhibition industry.

The questionnaire concludes three parts: 1) personal basic information: gender, age and education level; 2) basic information of individual participation in the exhibition: the frequencies and types of exhibitions one participated in and the personal roles in the exhibition; 3) the main part of the questionnaire: multiple items of variables such as atypical visitors' interactive learning with exhibition organizers, with exhibitors and with other visitors, experience value and exhibition brand equity.

The Likert five-point scale was used to measure the three dimensions and seven variables of the questionnaire by dividing the grades from 1 - 5 to indicate the degrees from disagreement to agreement.

The random sampling method on small samples was used to conduct a presurvey. Of 50 questionnaires distributed at two exhibitions, 50 collected and 48 valid. Through the factor analysis of the measurement items of atypical visitors' interactive learning behavior, experience value and exhibition brand equity by SPSS22.0, the results show that all the items have the factor loadings greater than 0.5. The design of questionnaire items is reasonable, and final scale can be seen in Table 1.

\section{Empirical Analysis}

\subsection{Data Collection and Analysis Method}

The investigation method of on-site distribution and on-site collection was used. China Hi-Tech Fair 2019 held at Shenzhen Convention \& Exhibition Center was taken as the research object. Of 514 questionnaires distributed, 514 collected and 508 valid. The valid collection rate of the questionnaires was $98.8 \%$. Spss 22.0 was used as the statistical tool for analysis in this study.

\subsection{Samples Analysis}

\subsubsection{Basic Information Analysis}

The descriptive analysis results of the samples show that (Table 2): 
1) Basic information of samples: there was no significant difference between male (53.9\%) and female (46.1\%); respondents were mainly young people: concentrated in the 18 - 35 and 26 - 35 age groups, accounting for $78 \%$ of the total; respondents were well-educated: mainly with education level of junior college and undergraduate, accounting for $78 \%$ of the total.

2) Samples exhibition experience: most of the samples had high participation frequencies and a certain degree of representativeness: the proportion of exhibition frequencies within 15 times is as high as $91.6 \%$.

3) Types of participated exhibitions: the higher proportion of exhibition type was technology exchange type, accounting for $39.5 \%$, and the proportions of other types were relatively average; most samples were technology-preferred.

4) Personal roles in the exhibition: Most samples in the exhibition were with scattered and diverse roles, of which professional and technical personnel, peer practitioners, suppliers and students/teachers/associations accounted for $18.9 \%$, $19.8 \%, 13.6 \%$ and $17.5 \%$, respectively.

\subsubsection{Normal Distribution Test}

The data analysis results of this study show that the maximum absolute values of kurtosis and skewness of 22 items in the questionnaire are $1.513(<5)$ and 1.03 $(<2)$ respectively, which are within the allowable ranges. The skewness and kurtosis of each item are basically reasonable, and the sample data follow normal distribution in this analysis.

\subsection{Reliability and Validity Analysis}

\subsubsection{Reliability Analysis}

The results of reliability analysis of the data show that in the overall reliability, the Cronbach $\alpha$ coefficient is $0.931>0.9$; in the component reliability analysis, the Cronbach $\alpha$ coefficients are among 0.802 and 0.875 , with the average level of

Table 2. Basic information of samples.

\begin{tabular}{|c|c|c|c|c|}
\hline $\begin{array}{l}\text { Demographic } \\
\text { characteristics }\end{array}$ & option & numbers & $\begin{array}{c}\text { Effective } \\
\text { percentage }\end{array}$ & $\begin{array}{l}\text { Cumulative } \\
\text { percentage }\end{array}$ \\
\hline \multirow{2}{*}{ Gender } & male & 277 & 53.9 & 53.9 \\
\hline & female & 237 & 46.1 & 100.0 \\
\hline \multirow{5}{*}{ age } & $\leq 18$ & 21 & 4.1 & 4.1 \\
\hline & $18-25$ & 217 & 42.2 & 46.3 \\
\hline & $26-35$ & 184 & 35.8 & 82.1 \\
\hline & $36-45$ & 60 & 11.7 & 93.8 \\
\hline & $\geq 46$ & 32 & 6.2 & 100.0 \\
\hline \multirow{4}{*}{ education level } & High school and below & 61 & 11.9 & 11.9 \\
\hline & academy & 160 & 31.1 & 43.0 \\
\hline & Undergraduate & 241 & 46.9 & 89.9 \\
\hline & Master degree or above & 52 & 10.1 & 100.0 \\
\hline
\end{tabular}


greater than 0.7 , which shows good internal consistent reliability. The questionnaire is with a high overall reliability.

\subsubsection{Validity Analysis}

The reliability of the questionnaire is measured by KMO and Bartlett sphericity test. The results of validity analysis of the data show that: KMO values of each dimension are 0.896, 0.778 and 0.900 , respectively, with the average level of greater than 0.7; the degrees of freedom of the Bartlett sphericity test are 6 and 36 respectively with the corresponding significance is $0.000(P<0.001)$, which is significant. The questionnaire is with a high overall validity.

\subsection{Data Analysis and Hypothesis Testing}

\subsubsection{Exploratory Factor Analysis}

In this study, the principal component analysis method of exploratory factor analysis is used to reduce the dimensions of atypical visitors' interactive learning, experience value and exhibition brand equity, and the interpretation features are extracted. The main results are as follows (Table 3).

1) Three main factors of atypical visitors' interactive learning.

The first main factor includes three items: "I had a lot of opportunities to communicate and learn with other visitors during the exhibition"; "I had a passionate communication with other visitors"; "I felt happy by communicating with other visitors", and the factor loadings are $0.733,0.815$ and 0.844 , respectively.

The second main factor includes three items: "Exhibitors were willing to take the time to communicate with me"; "The exhibitors had a face-to-face and warm communication with me to understand my needs"; "Exhibitors honestly shared information of enterprises, products or technologies with me", and the factor loadings are $0.779,0.818$ and 0.790 , respectively.

The third main factor includes three items: "Exhibition organizers responded to or meet my service requirements in a timely manner"; "Exhibition organizers provided me with communication opportunities by holding forum activities and other forms"; "Exhibition organizers listened carefully to my feedback", and the factor loadings are $0.837,0.792$ and 0.754 , respectively.

The factor loadings of the three principal components are all greater than 0.7, indicating that there is a good validity in the dimension of atypical visitors' interactive learning.

2) One main factor of experience value.

The main factor includes four items: "I felt happy to play my own role when I put forward my own opinions and suggestions in the process of interactive learning"; "I would have a sense of achievement if my opinions and suggestions are adopted by exhibition organizers or exhibitors"; "I would be happy when I reflect my needs, opinions and suggestions to exhibition organizers or exhibitors in interactive learning"; "Exhibition organizers or exhibitors would better meet my needs if I reflect my needs and put forward opinions and suggestions to 
Table 3. Interactive learning rotating component matrix.

\begin{tabular}{|c|c|c|c|c|}
\hline & \multirow{2}{*}{ items } & \multicolumn{3}{|c|}{ main factors } \\
\hline & & 1 & 2 & 3 \\
\hline \multirow{9}{*}{$\begin{array}{l}\text { atypical } \\
\text { visitors' } \\
\text { interactive } \\
\text { learning }\end{array}$} & $\begin{array}{l}\text { 1) Exhibition organizers responded to or meet } \\
\text { my service requirements in a timely manner. }\end{array}$ & 0.152 & 0.270 & 0.837 \\
\hline & $\begin{array}{l}\text { 2) Exhibition organizers provided me with } \\
\text { communication opportunities by holding forum } \\
\text { activities and other forms. }\end{array}$ & 0.246 & 0.204 & 0.792 \\
\hline & $\begin{array}{l}\text { 3) Exhibition organizers listened carefully } \\
\text { to my feedback. }\end{array}$ & 0.293 & 0.446 & 0.754 \\
\hline & $\begin{array}{l}\text { 4) Exhibitors were willing to take the time } \\
\text { to communicate with me. }\end{array}$ & 0.170 & 0.779 & 0.408 \\
\hline & $\begin{array}{l}\text { 5) The exhibitors had a face-to-face and } \\
\text { warm communication with me to } \\
\text { understand my needs. }\end{array}$ & 0.173 & 0.818 & 0.180 \\
\hline & $\begin{array}{l}\text { 6) Exhibitors honestly shared information of } \\
\text { enterprises, products or technologies with me. }\end{array}$ & 0.290 & 0.790 & 0.221 \\
\hline & $\begin{array}{l}\text { 7) I had a lot of opportunities to } \\
\text { communicate and learn with other } \\
\text { visitors during the exhibition. }\end{array}$ & 0.733 & 0.270 & 0.260 \\
\hline & $\begin{array}{l}\text { 8) I had a passionate communication } \\
\text { with other visitors }\end{array}$ & 0.815 & 0.288 & 0.135 \\
\hline & $\begin{array}{l}\text { 9) I felt happy by communicating with } \\
\text { other visitors }\end{array}$ & 0.844 & 0.097 & 0.197 \\
\hline \multirow[b]{3}{*}{$\begin{array}{l}\text { experience } \\
\text { value }\end{array}$} & $\begin{array}{l}\text { 10) I felt happy to play my own role when I put } \\
\text { forward my own opinions and suggestions in } \\
\text { the process of interactive learning. }\end{array}$ & 0.766 & & \\
\hline & $\begin{array}{l}\text { 11) I would have a sense of achievement if } \\
\text { my opinions and suggestions are adopted by } \\
\text { exhibition organizers or exhibitors. }\end{array}$ & 0.788 & & \\
\hline & $\begin{array}{l}\text { 12) I would be happy when I reflect my needs, } \\
\text { opinions and suggestions to exhibition } \\
\text { organizers or exhibitors in interactive } \\
\text { learning. } \\
\text { 13) Exhibition organizers or exhibitors } \\
\text { would better meet my needs if I reflect my needs } \\
\text { and put forward opinions and } \\
\text { suggestions to them. }\end{array}$ & 0.758 & & \\
\hline \multirow{9}{*}{$\begin{array}{l}\text { exhibition } \\
\text { brand equity }\end{array}$} & $\begin{array}{l}\text { 14) When talking about similar exhibitions, } \\
\text { I often think of this exhibition. }\end{array}$ & 0.379 & 0.198 & 0.844 \\
\hline & 15) I am very familiar with this exhibition. & 0.294 & 0.147 & 0.792 \\
\hline & $\begin{array}{l}\text { 16) Many people I am familiar with know about } \\
\text { this exhibition. }\end{array}$ & 0.212 & 0.208 & 0.803 \\
\hline & 17) I think this is a high-quality exhibition. & 0.146 & 0.747 & 0.322 \\
\hline & $\begin{array}{l}\text { 18) I think the visitors of this exhibition } \\
\text { are of high quality. }\end{array}$ & 0.453 & 0.629 & 0.030 \\
\hline & $\begin{array}{l}\text { 19) I am satisfied with the service of the } \\
\text { exhibitors in this exhibition. }\end{array}$ & 0.210 & 0.793 & 0.146 \\
\hline & 20) I will participate in this exhibition next time. & 0.717 & 0.232 & 0.300 \\
\hline & 21) I will recommend this exhibition to others. & 0.812 & 0.251 & 0.138 \\
\hline & 22) I will invite others to visit the exhibition & 0.781 & 0.214 & 0.294 \\
\hline
\end{tabular}


them", and the factor loadings of $0.766,0.788,0.781$ and 0.758 respectively are all greater than 0.7 , indicating that there is a good validity in the dimension of experience value.

3) Three main factors of exhibition brand equity.

The first main factor includes three items: "I will participate in this exhibition next time"; "I will recommend this exhibition to others"; "I will invite others to visit the exhibition", and the factor loadings of $0.717,0.812$ and 0.781 respectively are all greater than 0.7 .

The second main factor includes three items: "I think this is a high-quality exhibition"; "I think the visitors of this exhibition is of high quality"; "I am satisfied with the service of the exhibitors in this exhibition", and the factor loadings are $0.747,0.629$ and 0.793 , respectively.

The third main factor includes three items: "When talking about similar exhibitions, I often think of this exhibition"; "I am very familiar with this exhibition"; "Many people I am familiar with know about this exhibition", and the factor loadings are $0.844,0.792$ and 0.803 , respectively.

The factor loadings of the three principal components are all greater than 0.7 , indicating that there is a good validity in the dimension of exhibition brand equity.

\subsubsection{Correlation Analysis}

The correlation among the factors of atypical visitors' interactive learning, experience value and exhibition brand equity is analyzed. The results (can be seen in Table 4) show that the correlation significance among the factors is less than 0.01 , which is highly significant. The Pearson correlation coefficients are among 0.4 to 0.7 , showing moderately and significantly positive correlations. The main results are as follows.

1) Atypical visitors' interactive learning with exhibition organizers has a moderately and significantly positive impact on experience value, brand awareness, brand's perceived quality and brand loyalty.

2) Atypical visitors' interactive learning with the exhibitors has a moderately and significantly positive impact on experience value, brand awareness, brand's perceived quality and brand loyalty.

3) Atypical visitors' interactive learning with other visitors has a moderately and significantly positive impact on experience value, brand awareness, brand's perceived quality and brand loyalty.

4) Experience value has a moderately and significantly positive impact on brand awareness, brand's perceived quality and brand loyalty.

\subsubsection{Regression Analysis}

1) Multiple regression analysis of atypical visitors' interactive learning on experience value.

The results (can be seen in Table 5) of multiple regression analysis on the three factors of atypical visitors' interactive learning and experience value show 
Table 4. Correlation analysis of research variables.

\begin{tabular}{|c|c|c|c|c|c|c|c|}
\hline & $\begin{array}{c}\text { Interactive } \\
\text { learning } \\
\text { with } \\
\text { exhibition } \\
\text { organizers }\end{array}$ & $\begin{array}{l}\text { Interactive } \\
\text { learning } \\
\text { with } \\
\text { exhibitors }\end{array}$ & $\begin{array}{l}\text { Interactive } \\
\text { learning } \\
\text { with other } \\
\text { visitors }\end{array}$ & $\begin{array}{c}\text { Experience } \\
\text { value }\end{array}$ & $\begin{array}{c}\text { Brand } \\
\text { awareness }\end{array}$ & $\begin{array}{l}\text { Brand's } \\
\text { perceived } \\
\text { quality }\end{array}$ & $\begin{array}{l}\text { Brand } \\
\text { loyalty }\end{array}$ \\
\hline $\begin{array}{l}\text { Interactive } \\
\text { learning with } \\
\text { exhibition } \\
\text { organizers }\end{array}$ & 1 & & & & & & \\
\hline $\begin{array}{l}\text { Interactive } \\
\text { learning with } \\
\text { exhibitors }\end{array}$ & $0.675^{* *}$ & 1 & & & & & \\
\hline $\begin{array}{l}\text { Interactive } \\
\text { learning with } \\
\text { other visitors }\end{array}$ & $0.551^{* *}$ & $0.550^{\star *}$ & 1 & & & & \\
\hline $\begin{array}{l}\text { Experience } \\
\text { value }\end{array}$ & $0.540^{\star *}$ & $0.530^{\star *}$ & $0.555^{\star *}$ & 1 & & & \\
\hline $\begin{array}{l}\text { Brand } \\
\text { awareness }\end{array}$ & $0.523^{* *}$ & $0.531^{\star *}$ & $0.566^{\star *}$ & $0.560^{* *}$ & 1 & & \\
\hline $\begin{array}{l}\text { Brand's } \\
\text { perceived } \\
\text { quality }\end{array}$ & $0.472^{* *}$ & $0.439^{* *}$ & $0.431^{\star *}$ & $0.528^{* *}$ & $0.542^{\star *}$ & 1 & \\
\hline Brand loyalty & $0.557^{\star *}$ & $0.519^{\star *}$ & $0.559^{\star *}$ & $0.550^{\star *}$ & $0.655^{\star *}$ & $0.599^{* *}$ & 1 \\
\hline
\end{tabular}

${ }^{* *}$ There is a significant correlation at 0.01 level (bilateral).

Table 5. Regression analysis of atypical visitors' interactive learning on experience value.

\begin{tabular}{|c|c|c|c|c|c|c|c|c|}
\hline & \multirow{2}{*}{ Model } & \multicolumn{2}{|c|}{$\begin{array}{c}\text { Non-standardized } \\
\text { coefficient }\end{array}$} & \multirow{2}{*}{$\begin{array}{c}\text { Standard } \\
\text { coefficient } \\
\text { Trial } \\
\text { version }\end{array}$} & \multirow{2}{*}{$\mathrm{t}$} & \multirow{2}{*}{ Sig. } & \multicolumn{2}{|c|}{ Collinear statistic } \\
\hline & & $\mathrm{B}$ & $\begin{array}{l}\text { Standard } \\
\text { error }\end{array}$ & & & & Tolerance & VIF \\
\hline \multirow{5}{*}{1} & (Constant) & 1.472 & 0.139 & & 10.607 & 0.000 & & \\
\hline & $\begin{array}{l}\text { Interactive learning } \\
\text { with exhibition } \\
\text { organizers }\end{array}$ & 0.208 & 0.044 & 0.229 & 4.742 & 0.000 & 0.498 & 2.010 \\
\hline & $\begin{array}{l}\text { Interactive learning } \\
\text { with exhibitors }\end{array}$ & 0.183 & 0.044 & 0.200 & 4.131 & 0.000 & 0.498 & 2.007 \\
\hline & $\begin{array}{l}\text { Interactive learning } \\
\text { with other visitors }\end{array}$ & 0.262 & 0.035 & 0.319 & 7.477 & 0.000 & 0.638 & 1.567 \\
\hline & $\mathrm{R}=\mathrm{C}$ & $38 ; \mathrm{R}^{2}=$ & $.407 ;$ adju & ted $\mathrm{R}^{2}=0.4$ & $3 ; F=1$ & $6.62^{* *}$ & & \\
\hline
\end{tabular}

a. Dependent variable: experience value.

as follows.

The fitting index of experience value model is: bias correlation coefficient 0.638 , R2 0.407, adjusted R2 0.403, F value 116.62, significance less than 0.01 . Each item is highly significant, and the model passes the test of significance.

Experience value mainly depends on atypical visitors' interactive learning with 
exhibitors and other audiences, and there is no significant impact of atypical visitors' interactive learning with exhibition organizers on experience value.

2) Univariate regression analysis of experience value on exhibition brand equity.

The univariate regression analysis of the three factors of experience value on exhibition brand equity is conducted by the method of regression analysis with SPSS22.0 (results shown in Table 6).

The fitting index of the model of experience value and three factors of brand equity (brand awareness, brand's perceived quality and brand loyalty) is that the data is in bias relationship, and significance is less than 0.01 , which indicates each item is highly significant. The significance of the model coefficient is also less than 0.01 , indicating that the model is highly significant and passes the test of significance. The results show as follows.

a) Experience value has a significantly positive impact on brand awareness.

b) Experience value has a significantly positive impact on brand's perceived quality.

c) Experience value has a significantly positive impact on brand loyalty.

\subsection{Conclusions of Data Analysis}

The research results of this study (can be seen in Table 7) show that among the six hypotheses put forward previously, only one hypothesis is not supported, and the rest are supported.

Table 6. Regression analysis of experience value on brand equity.

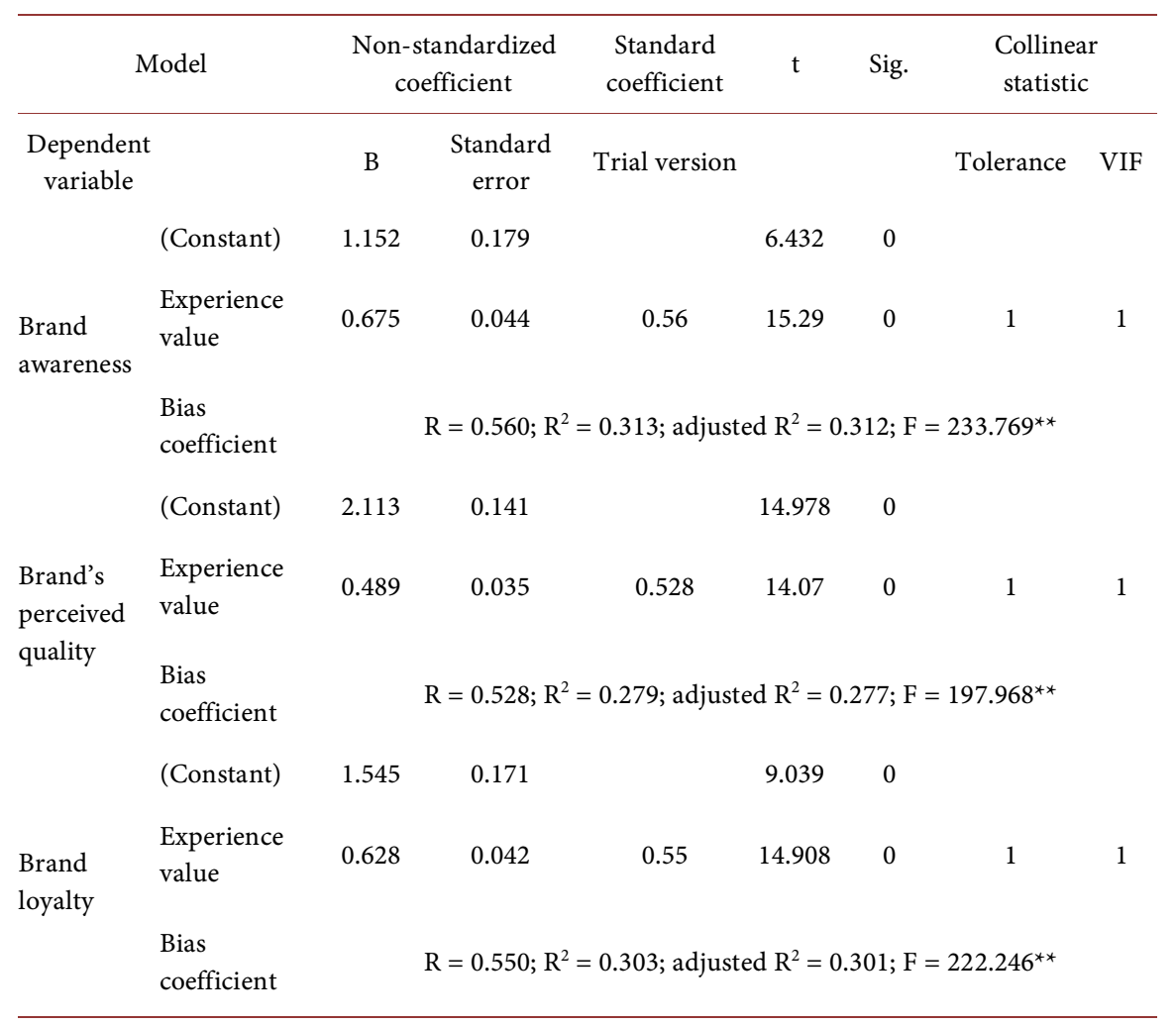


Table 7. Results of hypotheses testing.

\begin{tabular}{clc}
\hline Serial numbers & \multicolumn{1}{c}{ hypotheses contents } & \multicolumn{1}{c}{ Results } \\
\hline H1 & $\begin{array}{l}\text { Atypical visitors' interactive learning with exhibition } \\
\text { organizers has a significantly positive impact on } \\
\text { experience value. }\end{array}$ & not-supported \\
H2 & $\begin{array}{l}\text { Atypical visitors' interactive learning with exhibitors has a } \\
\text { significantly positive impact on experience value. }\end{array}$ & supported \\
& $\begin{array}{l}\text { Atypical visitors' interactive learning with other visitors } \\
\text { has a significantly positive impact on experience value. }\end{array}$ & supported \\
H3 & $\begin{array}{l}\text { Experience value has a significantly positive impact on } \\
\text { brand awareness. }\end{array}$ & supported \\
H5 & $\begin{array}{l}\text { Experience value has a significantly positive impact on } \\
\text { brand's perceived quality. }\end{array}$ & supported \\
& Experience value has a significantly positive impact on \\
brand loyalty. & supported \\
\hline
\end{tabular}

The results show as follows. Atypical visitors' interactive learning with exhibition organizers has no significantly positive impact on experience value. Atypical visitors' interactive learning with exhibitors and with other visitors have significantly positive impacts on experience value, in which atypical visitors' interactive learning with exhibitors has the greater impact on the experience value. Experience value has significantly positive impacts on three dimensions of exhibition brand equity: exhibition brand awareness, brand's perceived quality and brand loyalty.

\section{Conclusions and Suggestions}

\subsection{Research Conclusions}

\subsubsection{The Data Model of This Study Is Constructed Successfully}

Based on the data empirical analysis and results of hypotheses testing, the model of the influence of atypical visitors' interactive learning on exhibition brand equity is constructed successfully. The constructed model shows that atypical visitors can obtain high-quality exhibition experience value through multiple positive interactive learning with exhibition organizers, exhibitors and other visitors, thus having a positive impact on the exhibition brand equity.

\subsubsection{Atypical Visitors' Interactive Learning with Exhibitors Has the Greatest Impact on Experience Value}

Atypical visitors' interactive learning with exhibitors has the greatest impact on experience value, followed by atypical visitors' interactive learning with other visitors, and with exhibition organizers (having the least impact) in turn. In the type of Hi-Tech professional exhibition, atypical visitors can experience and visit more cutting-edge scientific and technological products and innovative ideas. They have access to knowledge and information beyond everyday cognition, and have a greater impact on their thinking than that of traditional exhibitions. After 
the communication with exhibitors, atypical visitors will pay more attention to the products, technology and brands visited on the exhibition, and even generate the buying desire and turn into typical visitors.

\subsubsection{Atypical Visitors' Interactive Learning with Other Visitors Has a Weaker Impact on Experience Value}

Generally speaking, atypical visitors mainly communicate with exhibitors and other visitors at the exhibition site, in which more often with exhibitors to obtain information than with other visitors. By the observation, imitation and learning with other visitors, atypical visitors can understand their own limitations, get more information and promote each other.

\subsubsection{Atypical Visitors' Interactive Learning with Exhibition Organizers Has No Significant Impact on Experience Value}

There are two reasons for this conclusion. Firstly, there is little interaction between atypical visitors and exhibition organizers in their participation in the exhibition, and the interaction mainly focuses on the exhibition service. Secondly, Most of the samples have plenty of exhibition experience, and 70\% of them are engaged in the exhibition-related industries, familiar with the responsibilities and work contents of exhibition organizers. Therefore, the decrease of interaction sensitivity and the purpose of technology exchange and acquisition of new knowledge have led to the fact that atypical visitors' interactive learning with exhibition organizers has an insignificant impact on experience value.

\subsubsection{Brand Loyalty Has the Greatest Impact on the Exhibition Brand Equity}

The results show that experience value has a direct and positive impact on exhibition brand equity. In the degrees of impact, brand loyalty has the greatest impact, brand awareness the second and brand's perceived quality the lowest.

\subsubsection{Brand's Perceived Quality Has the Greatest Impact on the Experience Value of Atypical Visitors' Interactive Learning}

The variables' mean values of brand equity show that brand's perceived quality (3.84) > brand loyalty (3.77) > brand awareness/association (3.461). Among them, atypical visitors have the highest evaluation of brand's perceived quality, mainly because they can experience more novel science and technology achievements at the professional and influential Hi-Tech Fair, and have a greater impact on their cognition.

\subsection{Suggestions}

\subsubsection{Face up to the Value and Contribution of Atypical Visitors}

When atypical visitors get a good interactive learning experience in the exhibition, their value and contribution to exhibition brand equity can not be ignored. Atypical visitors can be potential decision-makers of enterprises, contacts of key organizations and other groups, thus the long-term value of the atypical visitors to exhibition organizers and exhibitors should be paid more attention to. Both 
exhibition organizers and exhibitors should eliminate the long-term formed negative attitude of discrimination, restriction and even suppression against the atypical visitors, and take the initiative to create conditions and arrange time to actively communicate with atypical visitors.

\subsubsection{Give Full Play to the Role of Experience Value}

Through empirical analysis in this study, experience value has a significantly positive impact on the appreciation of exhibition brand equity. Through external systems such as products, services, atmosphere, senses, cognition and other experience elements offered by exhibition organizers, the deep docking of the multi-parties value chain among exhibitors, visitors and exhibition organizers can be realized to achieve tripartite win-win situation. Also, by promoting the interactive communication and improving the communication quality between visitors and visitors, and visitors and exhibitors, the tripartite win-win situation of exhibition brand, exhibitors' brands and visitors' experience value can be achieved.

\subsubsection{Attach Importance to the Accumulation of Exhibition Brand Equity}

Attaching importance to the accumulation of exhibition brand equity can effectively attract exhibitors and visitors, reduce exhibition marketing costs, cultivate the loyalty of exhibitors and visitors, and form the core resources of the exhibition. There are three ways to accumulate exhibition brand equity as follows. Firstly, communication resources should be integrated and the exhibition brand publicity should be increased to improve brand awareness. Secondly, the service quality of the exhibition should be improved to enhance the perceived quality of visitors and exhibitors. Lastly, the emotional stickiness of visitors and exhibitors should be enhanced to improve their brand loyalty.

\subsection{Limitations of Research}

The limitation of this research is mainly based on the definition of atypical visitor. The range of atypical visitors is very wide and this research does not point out the difference among them. And however, this sample of this research is collected during three days of one exhibition. With continuous years of data collection, the result will be more convincing.

\section{Conflicts of Interest}

The authors declare no conflicts of interest regarding the publication of this paper.

\section{References}

Aaker, D. A. (1991). Managing Brand Equity: Capitalising on the Value of a Brand Name. New York: The Free Press.

Aaker, D. A. (1996). Measuring Brand Equity across Products and Markets. California Management Review, 38, 103. https://doi.org/10.2307/41165845

Blythe, J. (2002). Using Trade Fairs in Key Account Management. Industrial Marketing 
Management, 31, 627-635. https://doi.org/10.1016/S0019-8501(02)00183-9

Blythe, J. (2010). Trade Fairs as Communication: A New Model. Journal of Business and Industrial Marketing, 25, 57-62. https://doi.org/10.1108/08858621011009155

Bonner, J. M. (2010). Customer Interactivity and New Product Performance: Moderating Effects of Product Newness and Product Embeddedness. Industrial Marketing Management, 39, 485-492. https://doi.org/10.1016/j.indmarman.2008.11.006

Borghini, S., Golfetto, F., \& Rinallo, D. (2006). Ongoing Search among Industrial Buyers. Journal of Business Research, 59, 1151-1159. https://doi.org/10.1016/j.jbusres.2006.06.005

Dube, L., \& Jordan, L. L. (2003). The Content and Structure of Laypeople's Concept of Pleasure. Cognition and Emotion, 17, 263-295. https://doi.org/10.1080/02699930302295

Fu, G. Q. (1999). Research of Trademark Assets. Wuhan University Journal, 1, 1000-5374.

Gan, J. (2013). Research on the Formation of Exhibition Brand Equity on the Exhibitors' Perspective. M.A. Thesis, Guangzhou: South China University of Technology.

Godar, S. H., \& O’Connor, P. J. (2001). Same Time Next Year-Buyer Trade Show Motives. Industrial Marketing Management, 30, 77-86. https://doi.org/10.1016/S0019-8501(99)00100-5

Hansen, K. (1996). The Dual Motives of Participants at International Trade Shows. International Marketing Review, 2, 39-55. https://doi.org/10.1108/02651339610115764

Harris, W. E., \& Moore, P. J. (2005). Sperm Competition and Male Ejaculate Investment in Nauphoetacinerea: Effects of Social Environment during Development. Journal of Evolutionary Biology, 18, 474-480. https://doi.org/10.1111/j.1420-9101.2004.00816.x

He, H. W., Cui, L. G., \& Wang, J. (2014). A Study of the Influencing Factors on Exhibitor Performance from an Interaction Perspective: The Value and Contribution of Atypical Visitors. Nankai Business Review, 17, 42-151.

Hua, Q. H. (2004). Exhibition Planning and Marketing. Guangzhou: Guangdong Economic Publishing House.

Jacoby, J., \& Robert, C. (1978). Brand Loyalty Measurement and Management. New York: John Wiley\& Sons.

Keller, K. L. (1993). Conceptualizing, Measuring, and Managing Customer-Based Brand Equity. The Journal of Marketing, 57, 1-22. https://doi.org/10.1177/002224299305700101

Kim, P. (1990). A Perspective on Brands. Journal of Consumer Marketing, 7, 63-67. https://doi.org/10.1108/EUM0000000002590

Kim, W. G., \& Kim, H. B. (2004). Measuring Customer-Based Restaurant Brand Equity: Investigating the Relationship between Brand Equity and Firms' Performance. Cornell Hotel and Restaurant Administration Quarterly, 45, 115-131. https://doi.org/10.1177/0010880404264507

Krystallis, A., \& Chrysochou, C. (2014). The Effects of Service Brand Dimensions on Brand Loyalty. Journal of Retailing and Consumer Services, 21, 139-147. https://doi.org/10.1016/j.jretconser.2013.07.009

Lee, C. H., \& Kim, S. Y. (2008). Differential Effects of Determinants on Multi-Dimensions of Tradeshow Performance: By Three Stages of Pre-Show, At-Show, and Post-Show Activities. Industrial Marketing Management, 37, 784-796. https://doi.org/10.1016/j.indmarman.2008.01.006

Li, L. J. (2012). Study on Co-Creating Touristic Experience Value-A Case of Beijing 
Xiangshan Park. PhD Dissertation, Beijing: Beijing Forestry University.

Li, L. Y. (2005). Relationship Learning at Trade Shows: Its Antecedents and Consequences. Industrial Marketing Management, 35, 166-177. https://doi.org/10.1016/j.indmarman.2005.03.006

Li, Q. G., \& Yu, M. Y. (2011). The Dynamic Effects of Brand Experience Value on Brand Equity. Journal of Systems \& Management, 20, 744-751.

Luo, Q. J., \& Bao, J. G. (2007). Study on Visitors Objectives of Attending Exhibitions and its Categories-A Case Study of Dongguan International Machinery \& Materials Exhibition. Journal of Guilin Institute of Tourism, 5, 731-735.

Ni, W. Y. (2017). A Research on the Mechanism of Value Co-Creation Based on the EXhibitor's Perspective. M.A. Thesis, Guangzhou: South China University of Technology.

Ning, C. H. (2005). Modeling the Utility-Based Br and Equity and Application. China Industrial Economy, 10, 124-126.

Ren, J. H. (2010). Research on the Strategy of Zhengzhou's Own Exhibition Brand Cultivation. Jiangsu Commercial Forum, No. 7, 92-94.

Rosson, P. J., \& Seringhaus, F. H. R. (1995). Visitor and Exhibitor Interaction at Industrial Trade Fairs. Journal of Business Research, 32, 81-90. https://doi.org/10.1016/0148-2963(94)00012-4

Schmitt, B. H. (1999). Experiential Marketing: How to Get Customers to Sense, Feel, Think, Act, Relate to Your Company and Brands. New York: The Free Press.

Sheth, J. N., Newman, B. I., Gross, B. L. (1991). Why We Buy What We Buy: A Theory of Consumption Values. Journal of Business Research, 2, 159-170. https://doi.org/10.1016/0148-2963(91)90050-8

Spiegel, \& Messenund, M. (1992). Deutschland, Fach and Wissen Band 9 (pp. 127-129). Hamburg: Verlag Rudolf Augstein GmgH \& Co., K. G.

$\mathrm{Su}$, J. (2008). The Research of Brand Construction of the Consumer Show Based on Customer Value. M.A. Thesis, Shanghai: Tongji University.

Tian, S. Q., \& Wang, D. Q. (2008). A Discussion on Experiential Exhibition Brand. Marketing Journal of Chongqing University of Arts and Science (Social Sciences Edition), 2,6 .

Tu, J. B., \& Chen, X. G. (2015). The Relations between User-to-User Interaction, Co-Creation User Experience and User Co-Created Value: An Example of Non-Trading Virtual Community. Wuhan University of Technology (Social Sciences Edition), No. 5, 942-948.

Wang, B. L. (2006). Exhibition Management. Beijing: Peking University Press.

Wang, C. H. (2012). A Study on Exhibitors Loyalty of Introduced Brand ExhibitionsCase Study of CGC EXPO. M.A. Thesis, Jinan: Shandong University.

Wang, D. Q., Zhou, Y., \& Tian, S. Q. (2008). Research on the Methods of Building Exhibition Brand and Sustainable Development. Commercial Age, 10, 24-25.

Wang, H. C., \& He, T. X. (2009). Analysis of the Factors Influencing the Satisfaction of Exhibition Exhibitors in China and Its Enlightenment. Journal of Changsha Railway University (Social Sciences Edition), 10, 30-32.

Wang, L. Z. \& Liao, R. (2010). Research on the Emotional Response of Brand Equity. Shanghai Enterprise, 11, 56-57.

Wei, H. Y., Yang, G. L., \& Liu, Y. C. (2010). Analysis of the Effects of Three Dimensional Interactions on Service Brand Relationship. Forecasting, 29, 12-18.

Yoo, B., \& Donthu, N. (2001). Developing and Validating a Multidimensional Consumer-Based Brand Equity Scale. Journal of Business Research, 52, 1-14. 
https://doi.org/10.1016/S0148-2963(99)00098-3

Yoo, J., Arnold, T. J., \& Frankwick, G. L. (2012). Effects of Positive Customer-to-Customer Service Interaction. Journal of Business Research, 65, 1313-1320. https://doi.org/10.1016/j.jbusres.2011.10.028

Yu, M. Y. (2009). A Course of Branding. Shanghai: Fudan University Press.

Zhang, C. J., \& Xu, H. (2019). The Mechanism of Exhibitors and Professional Visitors Participating in Value Co-Creation in Exhibitions: Quantitative Analysis Based on a Structural Equation Model. Tourism Tribune, 34, 57-70.

Zhang, L., Chen, C., \& Duan, Y. H. (2018). B2B Exhibition Audience Service Marketing Strategy Based on Experience Value. Jiangsu Commercial Forum, 4, 32-35.

Zhong, Y. (2007). On the Strategic Management of Exhibition Brand Based on the Evaluation Standard of Brand Exhibition. Market Modernization, 22, 217-218. 